\title{
Human Dignity and Human Rights: Fostering and Protecting Pluralism and Particularity
}

\author{
Peter G. Kirchschlaeger \\ Faculty of Theology, University of Lucerne, Lucerne, Switzerland \\ peter.kirchschlaeger@unilu.ch
}

\begin{abstract}
Human rights and their universality can lead to restrictions for individuals resulting from duties, which correspond to human rights of all human beings. This characteristic of human rights emphasizes the need for an ethical justification. Addressing the question of how human rights can be justified represents, therefore, an expression of respect for pluralism and particularity. Beyond that, human dignity and human rights lay the foundation for pluralism and particularity as they see all human beings as individuals that are all different and unique, and not as members of a collective. Only human rights protection of the autonomy of each individual allows all human beings to be particular and fosters pluralism. Finally, the concept of "adaptation" contributes to an understanding of the interaction between pluralism and particularity and human dignity and human rights as their foundation by capturing the relationship between human dignity and human rights and religious and worldview-based communities.
\end{abstract}

\section{Keywords}

autonomy - human dignity - human rights - particularity - pluralism - vulnerability

\section{Respecting Pluralism and Particularity by Justifying Human Dignity and Human Rights}

"All human beings are born free and equal in dignity and rights. They are endowed with reason and conscience and should act towards one another in a spirit of brotherhood." Article 1 of the Universal Declaration of Human Rights of 1948 expresses one of the eight essential characteristics of human rights: 
their universality. ${ }^{1}$ Human rights are universal because all human beings are holders of human rights - always, everywhere and without exception. The phrase "everybody matters"2 shows that human rights give the necessary protection to all human beings in all essential spheres and elements enabling the survival and the life as a human being.

The universality of human rights underpins the need for an ethical justification of human rights ${ }^{3}$, because human beings demand reasons for why human rights are also applicable to them. They ask for a justification for human rights and their corresponding duties, which might restrict them somehow.

The justifications are therefore pendent between the rights holder and the bearer of duties resulting from these rights. Both sides will only be able to accept a justification if this relation will be maintained and a justification will only seem adequate if it is applied to all persons concerned and will therefore be universal. ${ }^{4}$

\section{The Justification for Human Dignity and Human Rights Based on the Principle of Vulnerability}

The question of how the four statements above can be justified, can be answered with the justification approach based on the principle of vulnerability. The term "vulnerability"5 encompasses the possibility to be attacked or violated and, at the same time, a lack of ability or means to free oneself from this situation and to protect oneself from violations. ${ }^{6}$ The vulnerability originates in the physical and psychological helplessness of human beings towards themselves, fellow human beings, their context and their environment ${ }^{7}$, and their dependence on the world. Human beings are dependent on themselves, other human beings, the context and the environment in so far as they can, on the one hand, be violated by them and, on the other hand, be protected by them from violation. ${ }^{8}$ This shows a significant difference between the understanding of vulnerability and the term humiliation used by Avishai Margalit. He only

1 See in more detail Kirchschlaeger, Charakteristikum der Universalisierung, p. 301-312.

2 Appiah, Der Kosmopolit, p. 174.

3 Perry, Human Rights, p. 97-15o; Tasioulas, Human Rights, p. 45-70.

4 Lohmann, Menschenrechte, p. 10.

5 Kirchschlaeger, Wie können Menschenrechte begründet werden, p. 241-267; Kirchschlaeger, Das Prinzip der Verletzbarkeit; Kirchschlaeger, Justify Human Rights.

6 Schroeder/Gefenas, Vulnerability, p. 113-121; Kottow, Vulnerability, p. 281-287.

7 Ong-Vang-Cung, Reconaissance et vulnérabilité, p. 119.

8 Butler, Le pouvoir, p. 77 . 
traces humiliation back to human acts or omissions and not to the natural environment. ${ }^{9}$ Here, however, environment (understood as human and natural environment) is also meant in its second meaning, namely as a source of vulnerability for human beings, because it can touch upon essential elements and spheres of human existence, and because human beings have various options to deal with it and react to it. For example, human beings that fell victims to a natural disaster should not simply be left to their own devices, but should be supported.

This justification approach for human rights based on the principle of vulnerability contains a first, second, and third step in filtering, which will lead to the emergence of an ethical justification for human rights in general and for specific human rights.

\section{1 $\quad$ First Step of Filtering}

The justification approach based on the principle of vulnerability starts from the observation that human beings will recognize their own vulnerability - a first element of the principle of vulnerability. ${ }^{10}$ For example, the person who is healthy today knows that he or she might become ill tomorrow. Or - while living happily in the present - that he or she could be killed by others tomorrow. In this thought process, the person will go through a process of uncertainty, because he or she is made aware of his or her own vulnerability and, in the last consequence, his or her transience. ${ }^{11}$ This possibility of self-awareness is true for all human beings.

Second, an essential part of the principle of vulnerability is the "first-person perspective". ${ }^{2}$ The awareness-building of one's own vulnerability is a selfrecognition process of human beings, the empirical correctness of which is not relevant. It is crucial that human beings are willing to do something about this awareness of their vulnerability, namely, to protect themselves from vulnerability or to find a reasonable way to deal with it. This also affects all human beings.

During this awareness-building process when a human being becomes aware of his or her own vulnerability, he or she recognizes, ex negativo, the first-person perspective. This encompasses the awareness of the human being that he or she as a singular person is a subject of self-awareness through which

9 Margalit, The Decent Society, p. 9-10.

10 See in more detail Kirchschlaeger, Wie können Menschenrechte begründet werden, p. 231-267.

11 Hoffmaster, Vulnerability, p. 42.

12 Runggaldier, Grunderfahrungen, p. 143-221. 
one can access one's own vulnerability. On the other hand, the person experiences this basic anthropological situation of vulnerability as a subject (meaning as the first person singular). The acts, decisions, sufferings and the life of a human being originate from a person as subject. Furthermore, he or she interprets this basic anthropological situation of vulnerability as a subject and recognises the self-relation. ${ }^{13}$

Third, the vulnerability will be perceived and revealed by humans from their first-person perspective as well as for the first-person perspective itself and the self-relation.

This awareness-building process of one's own vulnerability and the firstperson perspective leads, fourth, to human beings relating themselves to all other human beings. In this process, they realize that the vulnerability does not make them different from other human beings, but that they share this vulnerability with all human beings.

Fifth, the process of realizing their own vulnerability and the vulnerability of all other human beings enables them to realize that they share not only the vulnerability with all other human beings, but also the individual first-person perspective on individual vulnerability and the vulnerability of all other human beings, as well as the individual self-relation: Every human being is subject of his or her own life. Human beings therefore realize that the first-person perspective and the self-relation is a prerequisite for life as a human being.

Based on the perception of vulnerability of their own first-person perspective and their own self-relation, they become aware of the same vulnerability of all other human beings. Human beings, who first and foremost want to survive and live as human beings, become aware that the vulnerability concerns their own survival as well as the survival of all other human beings, and also their own life as human beings and the lives of all others as human beings, because the vulnerability does not stop with the first-person perspective and the selfrelation as a prerequisite to human life. Faced with one's own vulnerability, the human being primarily wants to survive and live a dignified life. Survival and a dignified life should not be allowed to be taken away from human beings. They must be legally enforceable in order to offer real protection and have to be applicable to the various dimensions, because vulnerability can encompass the legal, political, historical and ethical dimension. Based on the abovementioned high priority they possess, and based on the unpredictability of the vulnerability, survival and a dignified life should be unconditional. Human beings share the desire to survive and live a dignified life with all other human beings equally. This desire is not individualistic, even if it is a concern of an

13 Honnefelder, Menschenrechtsbegründungen, p. 171 et seq. 
individual, which each individual discovers through his or her first-person perspective and self-relation.

Because, sixth, human beings are aware of their vulnerability, but at the same time do not know if and when this vulnerability will manifest itself and turn into a violation, they are prepared to accord all human beings the firstperson perspective and self-relation based on the equality of all human beings, because this presents the most rational and advantageous solution for themselves. Which means, to accord all human beings rights - that is to say human rights - in order to protect themselves and all others, since the vulnerability also contains the first-person perspective and the self-relation. On the one hand, this protection through human rights aims at avoiding the transformation of vulnerability into a concrete violation and, on the other hand, in the case of a possible transformation of vulnerability into a concrete violation, to receive active compensation. Humans are aware that the protection of human rights also encompasses the duties corresponding to the human rights, because they are not exclusive rights, but rights that all human beings are entitled to.

In view of the above-described awareness-building process for human rights, the question may arise as to why human beings should not opt for another form of self-limitation or another form of dealing with this situation (e.g. violence, subordination, etc.). As explained above, human beings are first and foremost interested in surviving and leading a dignified life. Human rights can best support this desire, which speaks in favor of human rights. On the other hand, violence or subordination - meaning alternative forms of protection against vulnerability and violation based on inequality and injustice among people (e.g. the powerful and the powerless, tyrants and subordinates, oppressors and oppressed) - can be excluded as rational and advantageous alternatives in view of the unpredictability of a possible transformation of vulnerability to violation because, due to the unpredictability of a possible transformation of vulnerability to violation, one does not know on which side one stands or will stand.

These six points on the principle of vulnerability explain that, seventh, the vulnerability in itself has no ethical quality, but the principle of vulnerability is normatively charged with the vulnerability, the first-person perspective and self-relation as an ethical claim. The principle of vulnerability affects all human beings and differentiates them from all other living beings. Because of the principle of vulnerability human beings accord each other human rights. Because they agree that, with human rights for themselves and all other human beings, a transformation from vulnerability into a concrete violation can be prevented or active compensation for all human beings would be provisioned in the case of a possible transformation of vulnerability into a concrete violation. It would 
be a decision by the moral society that human beings assign each other human rights based on the principle of vulnerability and consider all human beings as holders of human rights.

Therefore, human beings are not human rights holders because of their vulnerability, but they are human rights holders because they grapple with their own vulnerability and its relevance. They become aware of the first-person perspective and self-relation of themselves and all human beings, and they get to know the former as a prerequisite for human life. They even recognize the vulnerability of the first-person perspective and the self-relation of all human beings - because of the principle of vulnerability. Human beings differentiate vulnerability based on experiences of injustice and violations, and because of the principle of vulnerability they establish a protection of elements and spheres of human existence with specific human rights. The principle of vulnerability is therefore a starting point for justifying human rights per se as well as specific human rights.

Eighth, it is quite possible that the principle of vulnerability can be the basis for new suffering and experiences of injustice, which, because of their threatening character, will necessitate human rights protection. This necessity demands formulating rights that go beyond the human rights that exist today. The above-mentioned dynamic aligns with this possibility, which leaves human rights open to new opportunities and challenges that might arise. The principle of vulnerability contains an "exploratory function"14 that leads to the potential for unlimited evolution and differentiation of human rights.

These eight points make up the first step in filtering the justification model based on the principle of vulnerability. Not all elements and spheres of human existence are worth considering for protection through human rights, but only those that are needed due to the principle of vulnerability and are necessary for humans to protect themselves and others.

\subsection{Second Step of Filtering}

The second step of filtering builds on the considerations above and goes into more detail regarding the areas of protection that all human beings as holders of human rights are entitled to, because the consensus on the protection against vulnerability does not include all elements and spheres of human existence. However, which elements and spheres of human existence should be placed under the protection of human rights? What criteria should inform the selection of these elements and spheres of human existence?

14 Habermas, Menschenwürde, p. 18. 
Starting points for discerning these criteria are historical experiences of suffering and injustice, which human beings are or could be exposed to based on the principle of vulnerability. Faced with these historically severe experiences of injustice and violence, and because of the principle of vulnerability, human beings agree to prevent for themselves and all other human beings the transformation from vulnerability to concrete violation and to stipulate active compensation in the case of a possible transformation from vulnerability to concrete violation.

Human rights protection does not apply to all historic experiences of violation. It is necessary to make a selection of historic experiences of injustice that call for human rights protection, which again demands criteria for this selection process. They can be derived from the above descriptions of human beings and the above-described weighting, because it shows what human beings want to protect themselves against. It allows human beings to understand which characteristics must be fulfilled for a historical experience of violence to warrant protection through human rights. First of all, human beings want to survive and live as human beings (fundamentality). Human beings become aware that the vulnerability concerns their own survival and the survival of all human beings as well as their own life as human beings and the lives of all others as human beings (universality), because the vulnerability does not stop at the first-person perspective and self-relation as a prerequisite to human life. Survival and a dignified life should not be allowed to be taken away from human beings (inalienability). They must be legally enforceable (enforceability) and have to be applicable to various dimensions (multi-dimensionality), because vulnerability can encompass the legal, political, historical and ethical dimension. Based on the above-mentioned high priority they possess, and based on the unpredictability of the vulnerability or a possible transformation from vulnerability to violation, survival and a dignified life should be unconditional (categorical character). Human beings share this desire to survive and live a dignified life with all other human beings equally (equality). This desire is not individualistic, even if each individual discovers it through their own first-person perspective and self-relation (individual applicability). Therefore, the following eight criteria determine the choice of those historical experiences of violence and vulnerabilities against which all human beings should be protected through specific human rights: fundamentality, universality, inalienability, enforceability, multi-dimensionality, categorical nature, equality and individual applicability.

The second step in filtering the justification model based on the principle of vulnerability characterizes an inherent openness to new threats, risks, and experiences of injustice, which at present are not yet in the human conscience 
or imagination or have not yet occurred, as well as an openness for experiences of injustice that occur in different religions, cultures, traditions, civilizations, and world views.

At the same time, the second step of filtering leads to the challenges to apply these eight criteria to historical experiences of injustice, for example the challenges of historical contingency and the universalization of particular experiences of injustice.

\subsection{Third Step of Filtering}

This step encompasses the application of the above-mentioned eight criteria in order to identify the elements and spheres of human existence that need to be protected by human rights. Human rights per se and all specific human rights can be ethically justified based on the principle of vulnerability. ${ }^{15}$

Autonomy as Source of Pluralism and Particularity

Relying on their ethical justification, human dignity and human rights constitute the basis for pluralism and particularity by understanding all human beings as individuals that are all different and unique, and not simply members of a collective. Only the protection of human rights in its universality guarantees that all people are self-determined and can take their own positions and that those individual rights must be respected by all. Only this protection of autonomy of each individual allows all human beings to be particular. Therefore, human dignity and human rights take on a constitutive role for cultural, religious, and worldview-based pluralism and particularity, because the human rights-based appreciation of autonomy means at the same time celebrating particularity and, therefore, pluralism. ${ }^{16}$ Autonomy furthers - it is even a precondition for - pluralism and particularity, because without autonomy there would be no choice for the individual, which would make it very hard for pluralism and particularity. ${ }^{17}$

At the same time, pluralism and particularity are limited by human dignity and human rights of all human beings. ${ }^{18}$ The freedom of the individual is protected and simultaneously restricted by human rights (by human rights of all

15 Kirchschlaeger, Wie können Menschenrechte begründetwerden, p. 290-335; Kirchschlaeger, Das Prinzip der Verletzbarkeit, p. 121-141.

16 Kirchschlaeger, Menschenrechte und Religionen; Kirchschlaeger, Die Verantwortung.

17 Raz, Morality of Freedom, p. 395-399.

18 Marie, De l'universalité des principes, p. 225. 
other human beings) because, from a human rights perspective, one always has to accept the opposite as "an entity in a constant process of change; an entity we cannot quite imagine; an apparition in the process of becoming who faces us primarily to discomfort us and renegotiate both herself and ourselves." ${ }^{19}$ Rights and the corresponding duties interact with and restrict the arbitrary freedom of all human beings - for the protection of human dignity and human rights of all human beings.

Cultural, religious, and worldview-based pluralism and particularity go back to these individual rights and freedoms. They are indirectly protected by human rights through the individual human rights of all human beings. ${ }^{20}$ At the same time, there is a limit to religious and worldview-based pluralism and particularity, because religious and worldview-based communities have to respect, protect, enforce, and contribute to the realisation of human dignity and human rights inside and outside of their communities. Nevertheless, human dignity and human rights are not about levelling religious or worldview-based plurality. This would go against human dignity and human rights, which protect and promote religious or worldview-based pluralism and particularity indirectly by protecting the corresponding freedoms of the individual. By offering the preconditions and a framework for religious and worldview-based pluralism and particularity, human rights make it possible that difference becomes a reality and pluralism and particularity legitimate, even against resistance. ${ }^{21} \mathrm{It}$ would, for example, be conceivable that a religious or worldview-based community would deny people, who see themselves as being part of another or no religious or worldview-based community, the right to freedom of thought, conscience, and religion by referring to their own tradition, as well as cultural and religious pluralism and particularity. Therefore, human rights protection is needed for religious and worldview-based pluralism and particularity because it guarantees the autonomy of each human being. Religious and worldviewbased communities are free within the human rights framework (which means within the preconditions that also protect their own existence). This means, as a last consequence, that they are free, as long as they respect, protect, enforce, and contribute to the realisation of human dignity and human rights.

In this sense, human dignity and human rights secure a peaceful coexistence in a pluralistic society. Human dignity and human rights can be thought of as a branch on which hang the different religious and worldview-based communities, their peaceful coexistence, as well as religious and worldview-based

19 Gozdecka, Rights, p. 177.

$20 \quad$ Kirchschlaeger, Religionsfreiheit, p. 353-374.

21 Hoeffe, Rechtsprinzipien, p. 135-150. 
pluralism and particularity. This branch needs to be respected by religious and worldview-based communities - primarily because of the already established universal validity of human rights inside and outside of religious and worldview-based communities - and the corresponding responsibility of protecting, enforcing, and contributing to the enforcement of human rights must be fulfilled. Otherwise, religious and worldview-based communities are in danger of having their right of existence denied (particularly in contexts where they represent a minority). Also, they would endanger the peaceful coexistence of religious and worldview-based communities, the dialogue between religious and worldview-based communities, as well as religious and worldview-based pluralism and particularity as such and, therefore, saw off the branch they sit on.

The continued wrestling for common understanding between religious and worldview-based communities gets an ethically justified frame of reference $^{22}$ in human rights, which promotes respectful dealing with religious or worldview-based differences.

\section{Adaptation - a Model for Bringing Human Dignity, Human Rights, and Religious and Worldview-Based Communities Together}

In order to understand the interaction between pluralism and particularity and human dignity and human rights as their foundation, the concept of "adaptation" 23 tries to capture the relationship between human dignity and human rights and religious and worldview-based communities. Adaptation sees this relationship as coming together in dialogue, as meeting with reciprocal effect, and as continued interaction, within the limits of human dignity and human rights of all humans. First, adaptation considers the above-mentioned protection that human dignity and human rights indirectly offer to religious and worldview-based communities by protecting all humans in their mental, religious, worldview-based, and spiritual dimension of existence. With this first aspect of adaptation, human rights recognise - and take seriously - religious and worldview-based communities as objects of their protection, but also as duty-bearers.

Second, human dignity and human rights have a direct effect on religious and worldview-based communities, because the power and influence of religious

\footnotetext{
22 Kirchschlaeger, Wie können Menschenrechte begründet werden; Kirchschlaeger, Menschenrechte und Religionen.

23 Kirchschlaeger, Adaptation.
} 
and worldview-based communities also require the responsibility to respect, protect, enforce, and implement human dignity and human rights. Religious and worldview-based communities have a particular responsibility to use their power in accordance to and in favour of human dignity and human rights. All human beings everywhere in the world should know that they are not forgotten as holders of human dignity and human rights - inside and outside of religious and worldview-based communities. The adaptation of human dignity and human rights, therefore, takes religious and worldview-based communities as human rights actors seriously. It expects respect towards human dignity and human rights and contributes towards their protection, enforcement and realisation - it does not spare religious and worldview-based communities in this respect. At the same time, adaptation sees religious and worldview-based communities as partners that make sense of human dignity and human rights from their respective perspectives and that participate in the human rights discourse from their own position. In the course of adaptation, both lead to a greater identification with human dignity and human rights in religious and worldview-based communities, a deeper internalisation of human dignity and human rights, and a stronger ownership of human dignity and human rights. The criticism of religious and worldview-based communities of the human rights discourse and human rights practice and, reciprocally, of other or their own religious and worldview-based communities from a human rights perspective, always stays within the boundaries of human dignity and human rights when using adaptation.

Reciprocal criticism also means having the courage in the course of adaptation to "call human rights problems in religious communities by their name, to not simply accept appalling injustices in religious communities as God-given". ${ }^{24}$ Adaptation succeeds in creating a fertile and constructive foundation, because it sees the opposite not only as recipient of criticism, but also as sender of criticism that is embedded in the discourse depending on his or her self-conception.

The adaptation of human dignity and human rights proves to be dialogical when, during this process, religious and worldview-based communities also critically name developments in the human rights tradition, the human rights discourse, and human rights practice. ${ }^{25}$ As such, a religious or worldviewbased community could, for example, actively take a stand in the international human rights discourse when one category or generation of human rights is

24 Loretan, Menschenrechte, p. $5^{8}$ et seq.

25 Sauer/Riedl, Menschenrechte, p. 202-204. 
given more importance than another one on an international level and, through this, the principle of the indivisibility of human rights is not adhered to. Other religious and worldview-based communities name human rights violations of state and non-state actors and support victims of human rights violations and human rights defenders when they present their concerns and cases, introduce their perception of abuse and instrumentalization of human rights for other political causes (e.g. by states) into the human rights discourse, and criticise a lack of implementation and realisation of human rights for all people. The respect, protection, enforcement, and realisation of human dignity and human rights could benefit from the fact that religious and worldview-based communities are often very close to the action and witness events because of their institutionalisation and structures, and can report and bear witness to them by using their existing communication channels.

Third, adaptation aims at rendering for people in various contexts human dignity and human rights more tangible as their own human dignity and human rights. Using the word adaptation and not interpretation is deliberate. Because in the case of interpretation a change in content is definitely possible. For example, the Cairo Declaration on Human Rights in Islam of 1990 as an interpretation of human rights changes the content of human rights, inter alia, with article 24: "All the rights and freedoms stipulated in this Declaration are subject to the Islamic Sharia." This Sharia-reservation has an effect on the understanding of human rights as they are seen to be subordinate to Sharia.

Similarly, the Bangkok Declaration of Human Rights of 1993 also represents an interpretation of human rights because it changes the content of human rights, inter alia, with article 6: "Reiterate that all countries, large and small, have the right to determine their political systems, control and freely utilize their resources, and freely pursue their economic, social and cultural development." The first part of this article concerning the choice of political system leads to the fact that political participation rights are restricted by the selfdetermination of the state. A state could, therefore, constitute itself as a dictatorship with reference to this part of article 6 . This would mean giving up parts of the political participation rights.

Fourth, adaptation includes translating human dignity and human rights into the language, mindset, terms, concepts, narratives, pictures, and symbols of the respective religion and worldview. In the case of human rights as global consensus, there exists a need "of translating itself into a local project that speaks to peoples lived experiences. The international human rights project has been criticized as abstract in its pronouncements, elitist and alien to those it seeks to help. Largely driven by powerful Western-based NGO s, the 
international human rights movement has appeared to some in the developing world as a 'civilizing mission' that sometimes appears to suggest that local and domestic cultures are backward and at odds with human rights." 26

Fifth, adaptation incorporates human dignity and human rights into the horizon of belief, knowledge, thinking, and understanding of religious and worldview-based communities. This uncovers the contributions of the respective religious and worldview-based community to the emergence and development of human dignity and human rights. Furthermore, human dignity and human rights are correlated with their specific contents, convictions, teachings, principles, and values of the respective religious or worldview-based community. Human dignity and human rights are also rediscovered as part of one's own identity. In this way, human dignity and human rights can be related as the own to the own. In theology, in discourse, and in reflection within religious and worldview-based communities, a human rights oriented hermeneutic is used. ${ }^{27}$

Sixth, adaptation also encompasses religious and worldview-based justifications for human dignity and human rights. Based on the horizon of belief, knowledge, thinking, and understanding of the respective religious and worldview-based community, the claim that all humans are holders of human dignity and human rights will be justified.

Outside the respective religious and worldview-based community, the relevant justifications for human dignity and human rights based on religion or worldview might be limited. For the respect of human dignity and human rights within the respective religious or worldview-based community and for the perception of human rights duties for the respective religious or worldview-based community and its members, a religious and worldview-based justification for human dignity and human rights, cannot be estimated high enough in its importance, even if there is no necessity for it. No necessity, because an ethical justification for human dignity and human rights and their universality is also binding for religious and worldview-based communities.

The high importance of human dignity and human rights justifications based on religion or worldview stems from the fact that a justification based on religion or worldview is able to show that human dignity and human rights correspond to, for example, God's love or the love for God. ${ }^{28}$ Additionally, an

\footnotetext{
26 Ruteere, Valleys, p. 5.

27 Kirchschlaeger, Human Rights, p. 65-77; Kirchschlaeger, Menschenrechte als kontinuierliche Quelle, p. 227-250.

28 Raz, Morality of Freedom, p. 31 et seq; Assmann, Exodus.
} 
ethical justification for human dignity and human rights is needed so that all humans are offered a plausible and rational justification for human dignity and human rights. The unique and essential importance of religious and worldview-based justifications is based on the reinforcing effect that a religious and worldview-based justification for the validity of human dignity and human rights obtains inside the respective religious and worldview-based community, as well as for the respective religious and worldview-based community itself.

Without this additional religious and worldview-based justification of human rights one could, however, come to the conclusion that human dignity and human rights are something purely secular in the sense that they have no relevance for the respective religious and worldview-based community or its members. This conclusion, however, clearly contradicts the universality of human dignity and human rights.

The importance of this religious and worldview-based justification for human dignity and human rights becomes also obvious in view of the tendency to assume a religious or worldview-based space where human dignity and human rights allegedly do not apply. This tendency is based on the claim that a religious or worldview-based justification should be rejected out of respect for the general public and the secular character of human dignity and human rights. This tendency can only be countered with a justification within their own faith or worldview. Justifications based on religion and worldview give access to human dignity and human rights, in particular when emerging from a specific religion or worldview. According to this perspective, religious and worldview-based communities accept the invitation that was given implicitly during the preparatory phase of the 1948 Universal Declaration of Human Rights to develop various human rights justifications from religious or worldview-based perspectives, in order to respect pluralism and particularity, and to make human rights accessible for members and believers of a religion or worldview. On the one hand, this justification gives human rights the importance that they should have. On the other hand, it opens up the possibility to appreciate or use human rights as an ethical frame of reference in the respective religious and worldview-based community.

\section{Biography}

Professor of Theological Ethics and Director of the Institute of Social Ethics ISE at the Faculty of Theology of the University of Lucerne, and Research Fellow at the University of the Free State, Bloemfontein (South Africa). 
2011-2015 Member of the Board of the Swiss Centre of Expertise in Human Rights. 2011-2017 Member of the Expert-Jury of the Swiss Ethics Award. 2013 Visiting Scholar at the University of Technology Sydney (Australia). 20132014 Guest-Professor at the Faculty of Theology and Religious Studies at the Katholieke Universiteit Leuven (Belgium). 2013-2017 Fellow at the Raoul Wallenberg Institute of Human Rights and Humanitarian Law, Lund University (Sweden). 2015-2019 Guest-Lecturer at the Leuphana University Lueneburg (Germany). 2015-2017 Visiting Fellow at Yale University (USA).

\section{Bibliography}

Appiah, Kwame Anthony: Der Kosmopolit. Philosophie des Weltbürgertums. München: C.H. Beck, 2007 .

Assmann, Jan: Exodus. Die Revolution der Alten Welt. München: Verlag C.H. Beck, 2015.

Butler, Judith: Le pouvoir des mots. Politique du performatif. Paris: Éditions Amsterdam, 2004.

Gozdecka, Dorota Anna: Rights, Religious Pluralism and the Recognition of Difference. Off the scales of justice. New York, NY: Routledge, 2016.

Habermas, Jürgen: "Zur Legitimation durch Menschenrechte”, in: Hauke Brunkhorst/ Peter Niesen (ed.): Das Recht der Republik. Frankfurt a. M.: Suhrkamp, 1999, p. $386-403$.

Habermas, Jürgen: "Das Konzept der Menschenwürde und die realistische Utopie der Menschenrechte", in: Jürgen Habermas (ed.): Zur Verfassung Europas. Ein Essay. Berlin: edition suhrkamp, 2011, p. 13-38.

Höffe, Otfried: Kategorische Rechtsprinzipien. Frankfurt a. M.: Suhrkamp, 1990.

Hoffmaster, Barry: “What Does Vulnerability Mean?", in: The Hastings Center Report 36 (2/2006), p. 38-45.

Honnefelder, Ludger: "Theologische und metaphysische Menschenrechtsbegründungen", in: Arnd Pollmann/Georg Lohmann (ed.): Menschenrechte. Ein interdisziplinäres Handbuch. Stuttgart: J. B. Metzler, 2012, p. 171-178.

Hörnle, Tatjana: “Zur Konkretisierung des Begriffs 'Menschenwürde”, in:Jan C. Joerden/ Eric Hilgendorf/Natalia Petrillo/Felix Thiele (ed.): Menschenwürde und moderne Medizintechnik. Baden-Baden: Nomos, 2011, p. 57-76.

Kirchschlaeger, Peter G. (ed.): Die Verantwortung von nichtstaatlichen Akteuren gegenüber den Menschenrechten (Religionsrechtliche Studien 4), Zürich: Edition NZN bei TVZ, 2017.

Kirchschlaeger, Peter G.: “How Can We Justify Human Rights?”, in: International Journal of Human Rights and Constitutional Studies 4 (4/2016), p. 313-329. 
Kirchschlaeger, Peter G.: Menschenrechte und Religionen. Nichtstaatliche Akteure und ihr Verhältnis zu den Menschenrechten. Paderborn: Ferdinand Schöningh Verlag, 2016.

Kirchschlaeger, Peter G.: "Human Rights and Canon Law", in: Felix Wilfred, Andrés Torres Queiruga, Enrico Galavotti (ed.): Revision of Canon Law [= Concilium $5^{2}$ (5/2016)], p. 65-77.

Kirchschlaeger, Peter G.: "Adaptation - A Model for Bringing Human Rights and Religions Together", in: Acta Academica, 47 (2/2015), p. 163-191.

Kirchschlaeger, Peter G.: "Menschenrechte als kontinuierliche Quelle von Wertegeneralisierung", in: Jahrbuch für Christliche Sozialwissenschaften 56 (2015), p. $227-25$ o.

Kirchschlaeger, Peter G.: "Das Prinzip der Verletzbarkeit als Begründungsweg der Menschenrechte”, in: Freiburger Zeitschrift für Philosophie und Theologie 62 (1/2015), p. 121-141.

Kirchschlaeger, Peter G.: Wie können Menschenrechte begründet werden? Ein für religiöse und säkulare Menschenrechtskonzeptionen anschlussfähiger Ansatz. Münster: LIT-Verlag, 2013.

Kirchschlaeger, Peter G.: "Religionsfreiheit - ein Menschenrecht im Konflikt", in: Freiburger Zeitschrift für Philosophie und Theologie 6o (2/2013), p. 353-374.

Kirchschlaeger, Peter G.: "Das ethische Charakteristikum der Universalisierung im Zusammenhang des Universalitätsanspruchs der Menschenrechte”, in: Stephan Ast/Klaus Mathis/Julia Hänni/Benno Zabel (ed.): Gleichheit und Universalität (ARS P-Beiheft 128), Stuttgart 2011, p. 301-312.

Kottow, Michael H.: "Vulnerability. What Kind of Principle Is It?", in: Medicine, Health Care and Philosophy 7 (2004), p. 281-287.

Lohmann, Georg: "Die unterschiedlichen Menschenrechte", in: Karl Peter Fritzsche/ Georg Lohmann (ed.): Menschenrechte zwischen Anspruch und Wirklichkeit. Würzburg: Ergon Verlag, 200o, p. 9-23.

Loretan, Adrian: "Menschenrechte in den Religionsgemeinschaften", in: Peter G. Kirchschlaeger et al. (ed.): Menschenrechte und Wirtschaft im Spannungsfeld zwischen State und Nonstate Actors. Bern: Stämpfli Verlag (Internationales Menschenrechtsforum Luzern IHRF, 2), 2005, p. 51-59.

Margalit, Avishai: The Decent Society. Cambridge: Harvard University Press, 1998.

Marie, Jean-Bernard: "De l'universalité des principes à l'universalité des pratiques des droits de l'homme", in: Avancées et confins actuels des droits de l'homme aux niveaux international, européen et national. Mélanges offerts à Silvio Marcus Helmons. Brüssel: Bruylant, 2003, p. 219-229.

Ong-Van-Cung, Kim Sang: "Reconaissance et vulnérabilité", in: Archives de Philosophie 73 (2010), p. 119-141. 
Perry, Michael J.: “The Morality of Human Rights'. A Nonreligious Ground?”, in: Emory Law Journal 54 (2005), p. 97-150.

Raz, Joseph: The Morality of Freedom. Oxford: Clarendon House, 1986.

Runggaldier, Edmund: "Deutung menschlicher Grunderfahrungen im Hinblick auf unser Selbst”, in: Günter Rager/Josef Quitterer/Edmund Runggaldier (ed.): Unser Selbst - Identität im Wandel neuronaler Prozesse. Paderborn: Ferdinand Schöningh,

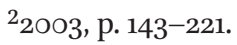

Ruteere, Mutuma: Bridging Valleys. Harnessing the Power of Religious Movements for and Human Rights. A Briefing Paper for the Raoul Wallenberg Institute for Human Rights and Humanitarian Law. Turkey, 2014 [unpublished].

Sauer, Hanjo/Riedl, Alfons: Die Menschenrechte als Ort der Theologie. Ein fundamentalund moraltheologischer Diskurs. Frankfurt a. M.: Peter Lang, 2003.

Schroeder, Doris/Gefenas, Eugenijus: “Vulnerability. Too Vague and Too Broad?", in: Cambridge Quarterly of Healthcare Ethics 18 (2009), p. 113-121.

Tasioulas, John: "On the Foundations of Human Rights", in: Rowan Cruft/ Matthew S. Liao/Massimo Renzo (ed.): Philosophical Foundations of Human Rights. Oxford: Oxford University Press, 2015, p. 45-70. 